\title{
HUBUNGAN KONSUMSI AIR, ASUPAN ZAT GIZI, DAN AKTIVITAS FISIK DENGAN PERSEN LEMAK TUBUH PADA REMAJA PUTRI
}

\author{
Habibaturochmah, Deny Yudi Fitranti*) \\ Program Studi Ilmu Gizi Fakultas Kedokteran Universitas Diponegoro \\ J1.Dr.Sutomo No.18, Semarang, Telp (024) 8453708, Email : gizifk@ undip.ac.id
}

\begin{abstract}
Background : Obesity is a condition caused by excessive accumulation of body fat. This accumulation can be attributed to the imbalance between energy intake and energy output. Water consumption can lose body fat percentage in adolescents girl.

Objective : Determine correlations of water consumption, nutrient intake, and physical activity with body fat percentage in adolescents girl.

Method : Observational study with cross-sectional design was conducted in Pangudi Luhur Domenico Savio Semarang junior high school in June of 2014. The study included 104 female students aged 13-15 years. Data on water consumption, nutrient intake were obtain using Food Frequency Questionnaire (FFQ) semi-quantitative. Data on body fat percentage was measured by Bioelectrical Impedance Analysis (BIA). Data on physical activity was obtained using International Physical Activity Questionnaire (IPAQ) short form. Bivariate analysis was analyzed by rank Spearman and $r$ Pearson Test.

Results : There are 29,8\% of subjects consumed less water than required. It was found that there was significant association between the consumption of water and body fat percentage ( $r=-0.596 ; p<0.05)$. Found also a significant association between the intake of carbohydrate and fat with body fat percentage $(r=-0.254 ; p=0.009$ and $r=0.429 ; p<0.05$, respectively). There was no significant association between intake of energy, protein, and physical activity with body fat percentage.

Conclusions : This study proved there was correlation between water consumption, carbohydrate, and fat intake with body fat percentage in adolescent girls. Carbohydrate and fat intake were predictor of body fat percentage in adolescent girls.
\end{abstract}

Keywords: water consumption; nutrient intake; body fat percentage; adolescents

\begin{abstract}
ABSTRAK
Latar belakang : Obesitas merupakan suatu kondisi akibat akumulasi lemak tubuh yang berlebihan. Kelebihan lemak tubuh dapat terjadi akibat ketidakseimbangan energi antara yang masuk dan energi yang keluar serta kurangnya aktivitas fisik. Konsumsi air dapat dikaitkan dengan penurunan persen lemak tubuh pada remaja putri.

Tujuan : Mengetahui hubungan konsumsi air, asupan zat gizi, dan aktivitas fisik dengan persen lemak tubuh pada remaja putri.

Metode : Penelitian observasional dengan pendekatan cross-sectional yang dilakukan di SMP Pangudi Luhur Domenico Savio Semarang pada bulan Juni 2014. Penelitian ini melibatkan 104 siswi berusia 13-15 tahun. Data konsumsi air, asupan energi, dan zat gizi diperoleh dengan menggunakan Food Frequency Questionaire (FFQ) semi kuantitatif. Data persen lemak tubuh diukur dengan Bioelectrical Impedance Analysis (BIA). Data aktivitas fisik diperoleh dengan menggunakan International Physical Activity Questionnaire (IPAQ) short form. Analisis bivarat dianalisis dengan uji rank Spearman dan r Pearson.

Hasil : Sebanyak 29,8\% subjek kurang mengonsumsi air. Didapatkan hubungan bermakna antara konsumsi air dengan persen lemak tubuh $(r=-0,596 ; p<0,05)$. Didapatkan pula hubungan bermakna antara asupan karbohidrat dan lemak dengan persen lemak tubuh (masing-masing nilai $r=-0,254 ; p=0,009$ dan $r=0,429 ; p<0,05$ ). Tidak terdapat hubungan yang bermakna antara asupan energi, protein, dan aktivitas fisik dengan persen lemak tubuh.

Kesimpulan : Dalam penelitian ini terbukti bahwa konsumsi air, asupan karbohidrat, dan asupan lemak mempunyai hubungan dengan persen lemak tubuh pada remaja putri. Asupan karbohidrat dan asupan lemak menjadi prediktor dari persen lemak tubuh pada remaja putri.
\end{abstract}

Kata kunci: konsumsi air; asupan energi dan zat gizi makro; persen lemak tubuh; remaja putri

\section{PENDAHULUAN}

Obesitas didefinisikan sebagai suatu kondisi akumulasi lemak tubuh yang berlebihan di jaringan adiposa. ${ }^{1}$ Kelebihan lemak tubuh dapat meningkatkan risiko penyakit kardiovaskuler, diabetes melitus tipe 2 dan beberapa jenis kanker. ${ }^{2}$
Obesitas dapat terjadi pada semua golongan usia termasuk remaja. ${ }^{3}$ Prevalensi obesitas pada remaja di Amerika pada tahun 2009-2010 mencapai $16,9 \%$ untuk kelompok umur 2-19 tahun sedangkan di Cina kurang lebih $10 \%$ anak berusia 7-17 tahun mengalami obesitas pada tahun 2007.4,5 
Tahun 2013 di Indonesia didapatkan prevalensi nasional obesitas penduduk usia 5-12 tahun sebesar $8,8 \%{ }^{6}$

Kelebihan lemak tubuh dapat terjadi akibat adanya ketidakseimbangan energi dalam tubuh yaitu asupan energi yang lebih besar dibanding dengan energy expenditure (keluaran energi) dalam jangka waktu lama. ${ }^{7}$ Energi yang berlebihan dari hasil metabolisme zat gizi makro akan disimpan di jaringan adiposa sebagai lemak tubuh. ${ }^{2}$ Penelitian di Amerika menunjukkan bahwa peningkatan rata-rata asupan energi sebesar 341 $\mathrm{kkal} /$ hari berdampak pada peningkatan prevalensi obesitas pada wanita dari $16,6 \%$ menjadi $36,5 \%$. Studi lain juga mengungkapkan bahwa asupan zat gizi berhubungan dengan persen lemak tubuh melalui mekanisme peningkatan insulin dan penurunan oksidasi lemak. ${ }^{9,10,11}$

Aktivitas fisik yang kurang juga dapat menjadi penyebab terjadinya penumpukan lemak tubuh. Penelitian di Amerika menunjukan bahwa $50 \%$ individu dengan tingkat aktivitas fisik rendah mempunyai risiko lebih besar dalam peningkatan simpanan lemak tubuh dibandingkan individu dengan aktivitas fisik tinggi. ${ }^{12}$ Aktivitas fisik dapat meningkatkan oksidasi lemak tubuh sehingga dapat menurunkan simpanan lemak tubuh di jaringan adiposa. ${ }^{13}$

Konsumsi air dapat dikaitkan dengan penurunan persen lemak tubuh. Sebuah penelitian membuktikan bahwa pemberian $500 \mathrm{ml}$ air selama 8 minggu dapat menurunkan persen lemak tubuh pada remaja putri obesitas. ${ }^{14}$ Mekanisme terjadinya penurunan lemak tubuh yaitu dengan adanya efek termogenesis air. Termogenesis air menyebabkan peningkatan oksidasi lemak dan penurunan oksidasi glukosa sehingga tubuh lebih banyak mengeluarkan energi dari cadangan energi yaitu lemak yang tersimpan dalam jaringan adiposa. ${ }^{15,16}$

Peningkatan prevalensi obesitas pada remaja dan belum banyak penelitian yang dilakukan mengenai hubungan konsumsi air, asupan zat gizi, dan aktivitas fisik dengan persen lemak tubuh pada remaja putri, melatarbelakangi penelitian ini. Manfaat dari penelitian ini adalah memberikan informasi pada masyarakat, khususnya remaja putri, bahwa penting dalam menjaga konsumsi air, asupan zat gizi, dan aktivitas fisik agar tidak terjadi peningkatan lemak tubuh.

\section{METODE}

Penelitian ini merupakan penelitian observasional dengan rancangan penelitian cross sectional. Subjek penelitian adalah siswi SMP Pangudi Luhur Domenico Savio Semarang berusia
13-15 tahun. Kriteria inklusi dalam penelitian ini meliputi bersedia menjadi subjek penelitian dengan mengisi informed consent, tidak merokok, tidak mengonsumsi alkohol, tidak mengonsumsi suplementasi yang mengandung kreatinin atau obat steroid, dan tidak menderita penyakit ginjal. Kriteria eksklusi penelitian ini yaitu mengundurkan diri dan meninggal dunia saat penelitian berlangsung.

Proses skrining untuk menentukan subjek penelitian dilakukan terhadap 285 siswi yang ditentukan dengan pengisian angket mengenai kriteria inklusi. Sebanyak 255 siswi masuk dalam kriteria inklusi kemudian dipilih dengan menggunakan simple random sampling sebanyak 104 orang sesuai dengan perhitungan besar sampel minimal menggunakan rumus estimasi proporsi. ${ }^{17}$

Variabel bebas (independent) dalam penelitian ini adalah konsumsi air, asupan energi, karbohidrat, protein, lemak, dan aktivitas fisik. Variabel tergantung (dependent) adalah persen lemak tubuh. Data yang diambil dalam penelitian ini antara lain data identitas sampel, data status gizi, data konsumsi air, data persen lemak tubuh, data asupan energi, karbohidrat, protein, dan lemak, dan data aktivitas fisik.

Data status gizi diambil sebagai data karakteristik subjek yang diperoleh dari pengukuran antropometri berupa tinggi badan dan berat badan kemudian dihitung IMT (Indeks Massa Tubuh) dan dikategorikan berdasarkan nilai $z$ score IMT/U yaitu obesitas (> +2 SD), overweight $(\geq+1$ SD hingga $\leq+2$ SD $)$, normal $(\geq-2$ SD hingga $<+1$ SD), kurus $(\geq-3$ SD hingga $<-2$ SD) dan sangat kurus $(<-3 \mathrm{SD}) .^{18}$

Konsumsi air didefinisikan sebagai jumlah asupan air sehari yang masuk ke dalam tubuh seseorang dari semua jenis minuman yang diperoleh dengan metode Food Frequency Questionnaire (FFQ) semi kuantitaf. Data konsumsi air yang diperoleh (ukuran rumah tangga) dikonversikan ke dalam satuan ml (mililiter) kemudian dikomparasikan dengan kebutuhan air masing-masing individu menggunakan rumus Darrow, yaitu konsumsi air = $1.500 \mathrm{~mL}+20 \mathrm{~mL}$ untuk setiap kg kenaikan BB di atas 20 kg. ${ }^{19}$ Tingkat kecukupan konsumsi air dikategorikan menjadi: baik jika konsumsi $\geq 90 \%$ dari kebutuhan sedangkan kategori kurang jika konsumsi $<90 \%$ dari kebutuhan.

Asupan energi, karbohidrat, protein, dan lemak didefinisikan sebagai jumlah energi, karbohidrat, protein, dan lemak dari makanan dan minuman yang diperoleh dengan metode Food Frequency Questionnaire ( $F F Q)$ semi quantitative. 
Data asupan yang diperoleh (ukuran rumah tangga) dikonversikan ke dalam satuan kalori dan gram kemudian dihitung nilai energi, karbohidrat, protein, dan lemak menggunakan program Nutrisurvey serta dikomparasikan dengan kebutuhan zat gizi masing-masing individu yang dihitung menggunakan rumus estimasi kebutuhan energi dari Institute of Medicine (IOM) yaitu kebutuhan energi $=160,3-30,8 \times$ Usia(tahun $)+$ koefisien aktivitas fisik $\mathrm{x} \quad(10 \mathrm{xBB}\langle\mathrm{kg}\rangle+$ 934xTinggi $<\mathrm{m}>)^{20} \quad$ Kebutuhan karbohidrat, protein, dan lemak masing masing dihitung sebesar $60 \%, 15 \%$, dan $25 \%$ dari total kebutuhan energi. Tingkat kecukupan asupan energi dinyatakan baik jika asupan 100-105\% dari kebutuhan. Tingkat kecukupan asupan karbohidrat, protein, dan lemak dinyatakan baik jika $80-100 \%$ dari kebutuhan. ${ }^{21}$

Aktivitas fisik yaitu skor aktivitas fisik seharihari dari subjek yang meliputi indeks kegiatan waktu sekolah, saat di perjalanan, di rumah, dan waktu luang yang diukur dalam satu minggu terakhir melalui wawancara dengan pengisian kuesioner IPAQ (International Physical Activity Questionnaire) short form. Perhitungan skor total pada short form adalah dengan menjumlahkan durasi (dalam menit), frekuensi (hari), dan intensitas (MET/metabolic equivalent) dari kegiatan berjalan, kegiatan dengan intensitas sedang (moderate) dan intensitas berat (vigorous). Kategori aktivitas fisik dinyatakan tinggi jika total skor $\geq 3000 \mathrm{MET}$-menit/minggu, kategori sedang jika total skor 600-2900 MET-menit/minggu, dan kategori rendah jika total skor $<600$ METmenit/minggu. ${ }^{22}$

Persen lemak tubuh dinyatakan sebagai perbandingan dari bobot massa lemak tubuh terhadap total berat badan dalam bentuk persen.
Data persen lemak tubuh diperoleh dari pengukuran dengan menggunakan BIA (Bio Impedance Analyzer). Kategori persen lemak tubuh diperoleh dari grafik persentil persen lemak tubuh berdasarkan usia. ${ }^{23}$

Analisis univariat dilakukan untuk mendeskripsikan data identitas sampel, status gizi, data konsumsi air, asupan energi, asupan karbohidrat, asupan protein, asupan lemak, aktivitas fisik, dan persen lemak tubuh. Data yang diperoleh diuji kenormalannya dengan menggunakan uji Kolmogorov Smirnov. Data yang berdistribusi tidak normal kemudian ditranformasi terlebih dulu hingga data berdistribusi normal. Analisis bivariat digunakan untuk mengetahui hubungan konsumsi air dan aktivitas fisik dengan persen lemak tubuh menggunakan

korelasi rank Spearman sedangkan hubungan asupan energi, karbohidrat, protein, dan lemak dengan persen lemak tubuh menggunakan uji $r$ Pearson. Kemudian dilanjutkan uji regresi linier ganda untuk mengetahui variabel prediktor dari persen lemak tubuh.

\section{HASIL PENELITIAN}

\section{Karakteristik subjek penelitian}

Penelitian dilaksanakan di SMP PL Domenico Savio Semarang pada bulan Juni 2014. Subjek penelitian merupakan siswi yang berusia 13-15 tahun berjumlah 104 orang.

Persen lemak tubuh subjek dalam penelitian ini adalah berkisar antara $10,6 \%$ hingga $43 \%$ dengan nilai rerata $26,9 \pm 8 \%$ (Tabel 1). Subjek yang termasuk dalam kategori persen lemak tubuh overfat dan obesitas adalah masing-masing $\begin{array}{llll}\text { sebanyak } & 12,5 \% & \text { (Tabel }\end{array}$

Tabel 1. Nilai Rerata dan Median pada Persen Lemak Tubuh, Tingkat Kecukupan Konsumsi Air, Asupan Energi, Asupan Zat Gizi, dan Aktivitas Fisik

\begin{tabular}{lccc}
\hline \multicolumn{1}{c}{ Variabel } & Mininum & Maksimum & $\begin{array}{c}\text { Mean } \pm \text { SD atau } \\
\text { Median }\end{array}$ \\
\hline Persen Lemak Tubuh (\%) & 10,6 & 43 & $26,9 \pm 8^{\mathrm{a}}$ \\
Tingkat Kecukupan Konsumsi Air (\%) & 47,9 & 139,3 & $100,6^{\mathrm{b}}$ \\
Tingkat Kecukupan Asupan Energi (\%) & 55,7 & 148,2 & $94 \pm 19,1^{\mathrm{a}}$ \\
Tingkat Kecukupan Asupan Karbohidrat (\%) & 28,2 & 156,1 & $87,5 \pm 22,7^{\mathrm{a}}$ \\
Tingkat Kecukupan Asupan Protein (\%) & 32,8 & 194,2 & $88,5 \pm 31,3^{\mathrm{a}}$ \\
Tingkat Kecukupan Asupan Lemak (\%) & 38,7 & 207,4 & $111,6 \pm 33,5^{\mathrm{a}}$ \\
Aktivitas Fisik (MET-menit/minggu) & 155,5 & 12528 & $2316^{\mathrm{b}}$ \\
Asupan Serat (gram) & 10,1 & 28,6 & 21,1 \\
\hline
\end{tabular}

${ }^{\mathrm{a}}$ Mean, ${ }^{\mathrm{b}}$ Median

Sebanyak 7 subyek $(6,7 \%)$ tergolong dalam kategori status gizi kurus dan satu subyek $(1 \%)$ tergolong dalam kategori sangat kurus sedangkan subjek yang mempunyai status gizi overweight dan obesitas adalah masing-masing sebanyak 24 subjek $(23,1 \%)$ dan 6 subjek $(5,8 \%)$. 
Tingkat kecukupan konsumsi air pada subjek berkisar antara 47,9\% hingga $139,3 \%$ dengan nilai median $100,6 \%$. Terdapat 31 subjek $(29,8 \%)$ yang masih kurang mengonsumsi air dari kebutuhan, diantaranya 15 subjek $(48,4 \%)$ termasuk dalam kategori overfat dan obesitas serta satu subjek $(3,2 \%)$ termasuk dalam kategori underfat (Tabel $3)$.

Tingkat kecukupan asupan energi subjek sebagian besar $(68,3 \%)$ tergolong kurang dan diantaranya 9 subjek $(12,7 \%)$ memiliki persen lemak underfat. Terdapat masing-masing 7 subjek $(26,9 \%)$ dan 3 subjek $(11,5 \%)$ yang tingkat kecukupan asupan energinya lebih tergolong dalam kategori overfat dan obesitas.
Rerata tingkat kecukupan asupan karbohidrat pada subjek adalah $87,5 \pm 22,7 \%$. Sebagian besar subjek $(78,8 \%)$ memiliki tingkat kecukupan asupan karbohidrat kurang, diantaranya 7 subjek $(8,5 \%)$ memiliki persen lemak underfat. Sebanyak 5 subjek $(27,8 \%)$ yang tingkat kecukupan asupan karbohidratnya lebih terdapat pada subjek yang persen lemaknya overfat dan obesitas.

Tingkat kecukupan asupan lemak pada subjek berkisar antara 38,7\% hingga 207,4\%. Asupan lemak subjek sebagian besar $(62,5 \%)$ tergolong berlebih dan diantaranya terdapat 12 subjek $(18,5 \%)$ tergolong dalam kategori overfat dan 11 subjek $(16,9 \%)$ tergolong dalam kategori obesitas.

Tabel 2. Karakteristik Subjek Penelitian

\begin{tabular}{|c|c|c|}
\hline \multirow{2}{*}{ Karakteristik } & \multicolumn{2}{|c|}{ Frekuensi } \\
\hline & $\mathbf{n}$ & $\%$ \\
\hline \multicolumn{3}{|l|}{ Status Gizi (Z-skor IMT/U) } \\
\hline Sangat Kurus $(<-3 \mathrm{SD})$ & 1 & 1,0 \\
\hline Kurus $\quad(\geq-3$ SD hingga $<-2$ SD $)$ & 7 & 6,7 \\
\hline$(\geq-2$ SD hingga $<+1 \mathrm{SD})$ & 66 & 63,5 \\
\hline Overweight $\quad(\geq+1$ SD hingga $\leq+2 \mathrm{SD})$ & 24 & 23,1 \\
\hline Obesitas $\quad(>+2 \mathrm{SD})$ & 6 & 5,8 \\
\hline \multicolumn{3}{|l|}{ Persen Lemak Tubuh } \\
\hline Underfat & 11 & 10,6 \\
\hline Normal & 67 & 64,4 \\
\hline Overfat & 13 & 12,5 \\
\hline Obesitas & 13 & 12,5 \\
\hline \multicolumn{3}{|l|}{ Tingkat Kecukupan Konsumsi Air } \\
\hline Kurang $(<90 \%)$ & 31 & 29,8 \\
\hline Baik $\quad(\geq 90 \%)$ & 73 & 70,2 \\
\hline \multicolumn{3}{|l|}{ Tingkat Kecukupan Asupan Energi } \\
\hline Kurang $(<100 \%)$ & 71 & 68,3 \\
\hline Baik $\quad(100-105 \%)$ & 7 & 6,7 \\
\hline Lebih $(>105 \%)$ & 26 & 25 \\
\hline \multicolumn{3}{|l|}{ Tingkat Kecukupan Asupan Karbohidrat } \\
\hline Kurang $(<80 \%)$ & 82 & 78,8 \\
\hline Baik $\quad(80-100 \%)$ & 4 & 3,8 \\
\hline Lebih $(>100 \%)$ & 18 & 17,3 \\
\hline \multicolumn{3}{|l|}{ Tingkat Kecukupan Asupan Protein } \\
\hline Kurang $(<80 \%)$ & 46 & 44,2 \\
\hline Baik $\quad(80-100 \%)$ & 25 & 24 \\
\hline Lebih $(>100 \%)$ & 33 & 31,7 \\
\hline \multicolumn{3}{|l|}{ Tingkat Kecukupan Asupan Lemak } \\
\hline Kurang $(<80 \%)$ & 16 & 15,4 \\
\hline Baik $\quad(80-100 \%)$ & 23 & 22,1 \\
\hline Lebih $(>100 \%)$ & 65 & 62,5 \\
\hline
\end{tabular}


Aktivitas Fisik

Rendah (<600 MET-menit/minggu)

18

47

17,3

Sedang (600-2900 MET-menit/minggu)

39

45,2

Tinggi ( $\geq 3000 \mathrm{MET}-\mathrm{menit} / \mathrm{minggu}$ ) 37,5

Hubungan Konsumsi Air, Asupan Energi, menggunakan uji rank Spearman dan $r$ Pearson Asupan Zat Gizi Makro, dan Aktivitas Fisik menunjukkan bahwa tingkat kecukupan konsumsi dengan Persen Lemak Tubuh

Tabel 4 menunjukkan korelasi antara variabelvariabel yang diambil dengan dengan persen air, asupan karbohidrat, dan asupan lemak memiliki hubungan yang signifikan dengan persen lemak tubuh. Berdasarkan hasil uji korelasi lemak tubuh dengan masing-masing nilai $\mathrm{p}<0,05$.

Tabel 3. Distribusi Frekuensi Kategori Persen Lemak Tubuh Menurut Kategori Tingkat Kecukupan Konsumsi Air, Asupan Zat Gizi, dan Aktifitas Fisik

\begin{tabular}{|c|c|c|c|c|c|}
\hline \multirow{2}{*}{ Variabel } & \multicolumn{4}{|c|}{ Kategori Persen Lemak Tubuh } & \multirow{2}{*}{ Total } \\
\hline & Underfat & Normal & Overfat & Obesitas & \\
\hline \multicolumn{6}{|l|}{ Tingkat Kecukupan } \\
\hline \multicolumn{6}{|l|}{ Konsumsi Air } \\
\hline Kurang $(<90 \%)$ & $1(3,2 \%)$ & $15(48,4 \%)$ & $7(22,6 \%)$ & $8(25,8 \%)$ & $31(100 \%)$ \\
\hline Baik $\quad(\geq 90 \%)$ & $10(13,7 \%)$ & $52(71,2 \%)$ & $6(8,2 \%)$ & $5(6,8 \%)$ & $73(100 \%)$ \\
\hline \multicolumn{6}{|l|}{ Tingkat Kecukupan } \\
\hline \multicolumn{6}{|l|}{ Asupan Energi } \\
\hline Kurang $(<100 \%)$ & $9(12,7 \%)$ & $46(64,8 \%)$ & $6(8,5 \%)$ & $10(14,1 \%)$ & $71(100 \%)$ \\
\hline Baik $\quad(100-105 \%)$ & 0 & $7(100 \%)$ & 0 & 0 & $7(100 \%)$ \\
\hline Lebih $(>105 \%)$ & $2(7,7 \%)$ & $14(53,8 \%)$ & $7(26,9 \%)$ & $3(11,5 \%)$ & $26(100 \%)$ \\
\hline \multicolumn{6}{|l|}{ Tingkat Kecukupan } \\
\hline \multicolumn{6}{|l|}{ Asupan Karbohidrat } \\
\hline Kurang $(<80 \%)$ & $7(8,5 \%)$ & $55(67,1 \%)$ & $10(12,2 \%)$ & $10(12,2 \%)$ & $82(100 \%)$ \\
\hline Baik $\quad(80-100 \%)$ & $1(25 \%)$ & $2(50 \%)$ & 0 & $1(25 \%)$ & $4(100 \%)$ \\
\hline Lebih $(>100 \%)$ & $3(16,7 \%)$ & $10(55,6 \%)$ & $3(16,7 \%)$ & $2(11,1 \%)$ & $18(100 \%)$ \\
\hline \multicolumn{6}{|l|}{ Tingkat Kecukupan } \\
\hline \multicolumn{6}{|l|}{ Asupan Protein } \\
\hline Kurang $(<80 \%)$ & $5(10,9 \%)$ & $28(60,9 \%)$ & $3(6,5 \%)$ & $10(21,7 \%)$ & $46(100 \%)$ \\
\hline Baik $\quad(80-100 \%)$ & $1(4 \%)$ & $19(76 \%)$ & $4(16 \%)$ & $1(4 \%)$ & $25(100 \%)$ \\
\hline Lebih $(>100 \%)$ & $5(15,2 \%)$ & $20(60,6 \%)$ & $6(18,2 \%)$ & $2(6,1 \%)$ & $33(100 \%)$ \\
\hline \multicolumn{6}{|l|}{ Tingkat Kecukupan } \\
\hline \multicolumn{6}{|l|}{ Asupan Lemak } \\
\hline Kurang $(<80 \%)$ & $7(43,8 \%)$ & $8(50 \%)$ & 0 & $1(6,2 \%)$ & $16(100 \%)$ \\
\hline Baik $\quad(80-100 \%)$ & $4(17,4 \%)$ & $17(73,9 \%)$ & $1(4,3 \%)$ & $1(4,3 \%)$ & $23(100 \%)$ \\
\hline Lebih $(>100 \%)$ & 0 & $42(64,6 \%)$ & $12(18,5 \%)$ & $11(16,9 \%)$ & $65(100 \%)$ \\
\hline \multicolumn{6}{|l|}{ Aktivitas Fisik } \\
\hline $\begin{array}{l}\text { Rendah }(<600 \text { MET- } \\
\text { menit/minggu })\end{array}$ & $3(16,7 \%)$ & $12(66,6 \%)$ & 0 & $3(16,7 \%)$ & $18(100 \%)$ \\
\hline $\begin{array}{l}\text { Sedang (600-2900 MET- } \\
\mathrm{menit} / \mathrm{minggu})\end{array}$ & $6(12,8 \%)$ & $28(59,6 \%)$ & $8(17 \%)$ & $5(10,6 \%)$ & $47(100 \%)$ \\
\hline $\begin{array}{l}\text { Tinggi ( } \geq 3000 \text { MET- } \\
\text { menit/minggu) }\end{array}$ & $2(5,2 \%)$ & $27(69,2 \%)$ & $5(12,8 \%)$ & $5(12,8 \%)$ & $39(100 \%)$ \\
\hline
\end{tabular}


Tingkat kecukupan konsumsi air terbukti berhubungan dengan persen lemak tubuh dengan nilai $r=-0.596$, artinya semakin tinggi konsumsi air maka semakin rendah persen lemak tubuh. Tingkat kecukupan asupan karbohidrat terbukti berhubungan bermakna dengan persen lemak tubuh dengan nilai $r=-0,254$, artinya semakin rendah asupan karbohidrat semakin tinggi persen lemak tubuh sedangkan tingkat kecukupan asupan lemak juga terbukti berhubungan dengan persen lemak tubuh dengan nilai $r=0,429$, artinya semakin tinggi asupan lemak maka semakin tinggi persen lemak tubuh pada remaja putri.

Tabel 4. Hubungan Tingkat Kecukupan Konsumsi Air, Asupan Zat Gizi, Aktivitas Fisik dengan Persen Lemak Tubuh

\begin{tabular}{lcc}
\hline \multicolumn{1}{c}{ Variabel } & \multicolumn{2}{c}{ Persen Lemak Tubuh } \\
\cline { 2 - 3 } & $\mathbf{~ r}$ & $\mathbf{p}$ \\
\hline Tingkat Kecukupan Konsumsi air (\%) & -0.596 & $0.0005^{\mathrm{a}}$ \\
Tingkat Kecukupan Asupan Energi (\%) & -0.014 & $0.890^{\mathrm{b}}$ \\
Tingkat Kecukupan Asupan Karbohidrat & -0.254 & $0.009^{\mathrm{b}}$ \\
$(\%)$ & & \\
Tingkat Kecukupan Asupan Protein (\%) & $-0,110$ & $0.265^{\mathrm{b}}$ \\
Tingkat Kecukupan Asupan Lemak (\%) & +0.429 & $0.0005^{\mathrm{b}}$ \\
Aktivitas Fisik (MET-menit/minggu) & +0.128 & $0.194^{\mathrm{a}}$ \\
\hline
\end{tabular}

${ }^{a}$ Uji korelasi rank Spearman, ${ }^{\mathrm{b}}$ Uji korelasi $r$ Pearson

Hasil analisis bivariat menunjukkan bahwa terdapat empat variabel yang memiliki $p<0,25$ antara lain tingkat kecukupan konsumsi air, karbohidrat, lemak, dan aktivitas fisik. Kemudian variabel-variabel tersebut dianalisis lebih lanjut menggunakan analisis regresi linier ganda untuk mengetahui variabel prediktor dari persen lemak tubuh. Hasil analisis regresi linier ganda menunjukkan bahwa variabel tingkat kecukupan asupan karbohidrat dan lemak menjadi variabel prediktor dari persen lemak tubuh dengan nilai koefisien regresi sebesar 0,515 dan konstanta 9,7. Angka Adjusted $R$ square adalah 0,265 menunjukkan bahwa $26,5 \%$ variasi persen lemak tubuh dapat dijelaskan oleh variasi tingkat kecukupan asupan karbohidrat dan lemak.

\section{PEMBAHASAN}

Hasil penelitian pada 104 remaja putri usia 13-15 tahun diketahui bahwa sebanyak 30 remaja $(28,9 \%)$ memiliki status gizi lebih. Hasil penelitian ini lebih tinggi dibandingkan dengan penelitian sebelumnya dimana terdapat $14,1 \%$ remaja usia 13-15 tahun mengalami obesitas. ${ }^{24}$

Persen lemak tubuh pada remaja putri berkisar antara 10,6\% hingga $43 \%$. Jika dilihat dari grafik persentil persen lemak tubuh berdasarkan usia, maka rentang tersebut termasuk dalam kategori normal yaitu 16-33\%. Hal ini juga tidak jauh berbeda dari penelitian sebelumnya bahwa rerata persen lemak tubuh pada remaja putri usia 13-15 tahun adalah $23,1 \pm 4,3 \% .^{24}$

Secara fisiologis, pada usia 13-15 tahun merupakan masa dimana seorang remaja mengalami perubahan dalam sistem pengaturan hormonal, salah satunya adalah hormon estrogen yang mempengaruhi terjadinya menarche (haid pertama). Menarche terjadi pada usia 10,5-15,5 tahun dimana pada saat itu terjadi penambahan lemak tubuh lebih tinggi dibandingkan sebelum menarche. Penambahan lemak tersebut akan digunakan sebagai cadangan energi selama masa kehamilan dan menyusui. ${ }^{25}$

Sebanyak 29,8\% remaja putri masih kurang mengonsumsi air dan hampir separuhnya $(48,4 \%)$ adalah remaja yang memiliki persen lemak tubuh overfat dan obesitas. Hasil tersebut juga tidak berbeda dengan penelitian pada remaja obesitas di Semarang pada Tahun 2012 bahwa konsumsi air pada remaja obesitas rata-rata hanya $994,9 \pm 383,6$ ml. ${ }^{26}$ Jumlah tersebut masih kurang dari kebutuhan air pada remaja obesitas karena kebutuhan air per individu dipengaruhi oleh berat badan. Orang yang obesitas memiliki total air tubuh lebih rendah dibandingkan dengan orang yang tidak obesitas karena kandungan air di dalam sel lemak lebih rendah daripada kandungan air di dalam sel otot sehingga orang yang obesitas lebih mudah mengalami kekurangan air dibandingkan dengan orang yang tidak obesitas. Oleh karena itu, orang obesitas mempunyai kebutuhan air yang lebih tinggi dibandingkan dengan orang yang tidak obesitas. ${ }^{19}$

Terdapat $62,5 \%$ remaja putri memiliki tingkat kecukupan asupan lemak lebih dan diantaranya sebanyak 23 remaja $(35,4 \%)$ termasuk dalam kategori overfat dan obesitas. Konsumsi lemak yang berlebihan akan lebih mudah disimpan oleh 
tubuh sebagai cadangan energi. Jika lemak tubuh yang disimpan akan semakin banyak maka akan terjadi penumpukan lemak tubuh yang berlebihan atau juga disebut dengan obesitas. ${ }^{1,11}$

Lain halnya dengan tingkat kecukupan asupan lemak, masing-masing terdapat $68,3 \%, 78,8 \%$, dan $44,2 \%$ remaja memiliki tingkat kecukupan energi, karbohidrat, dan protein kurang dari kebutuhan. Padahal masa remaja adalah masa dimana seseorang membutuhkan energi dan zat gizi yang cukup karena pada masa tersebut seseorang mengalami pertumbuhan dan perkembangan yang cepat. Kebutuhan energi dan zat gizi di usia remaja ditujukan untuk deposisi jaringan tubuhnya. Total kebutuhan energi dan zat gizi pada remaja lebih tinggi dibandingkan dengan rentang usia sebelumnya dan sesudahnya. Jika asupan energi dan zat gizi tidak mencukupi kebutuhan maka orang tersebut lebih berisiko untuk mengalami gangguan kesehatan.

Peneltian ini menunjukkan bahwa sebagian besar remaja putri $(45,2 \%)$ memiliki aktivitas fisik yang tergolong sedang. Hasil tersebut juga tidak berbeda dengan penelitian yang dilakukan sebelumnya pada remaja putri di Semarang bahwa $66,7 \%$ remaja putri memiliki aktivitas sedang. ${ }^{27}$ Remaja putri cenderung mempunyai aktivitas fisik yang lebih rendah dibandingkan laki-laki karena aktivitas fisik pada anak perempuan cenderung menurun saat awal pubertas.

Hasil uji hubungan pada penelitian ini menunjukkan bahwa tingkat kecukupan konsumsi air mempunyai hubungan yang bermakna dengan persen lemak tubuh pada remaja putri. Pemberian air sebanyak $500 \mathrm{ml}$ setiap hari selama 8 minggu memberikan pengaruh pada persen lemak tubuh remaja obesitas. ${ }^{14}$

Setelah mengonsumsi $500 \mathrm{ml}$ air, metabolisme tubuh akan meningkat 10 menit setelah konsumsi air dan mencapai maksimum setelah $\pm 30-40$ menit konsumsi air. ${ }^{15}$ Penelitian lain menyebutkan bahwa konsumsi $500 \mathrm{ml}$ air menyebabkan AMB (Angka Metabolisme Basal) meningkat hingga 24\% dalam 60 menit setelah konsumsi air. Adanya peningkatan metabolisme tubuh tersebut mengakibatkan terjadinya peningkatan pengeluaran energi oleh tubuh. Peningkatan pengeluaran energi akibat air disebut juga dengan efek termogenesis air. ${ }^{15,16}$

Awal mula terjadinya termogenesis adalah terjadinya pembentukan panas di jaringan coklat adiposa (brown adipose tissuel BAT) yang dirangsang dan diatur oleh sistem saraf simpatis. Noradrenalin mengikat B-3-receptors di jaringan coklat adiposa dan merangsang terjadinya lipolisis melalui cAMP-protein kinase A dan PPAR- $\alpha$ (Peroxisome Proliferator-Activated Receptor $\alpha$ ). PPAR- $\alpha$ kemudian mengaktifasi lipolisis dan oksidasi lemak sehingga terbentuk asam lemak bebas. Asam lemak bebas itu sendiri menjadi substansi yang mengakibatkan pelepasan fosforilasi oksidatif sehingga energi tidak diubah menjadi ADP atau ATP melainkan menjadi panas. Oleh karena itu, energi yang dikeluarkan lebih banyak dari cadangan energi yaitu lemak yang tersimpan dalam jaringan adiposa sehingga hal itulah yang diduga dapat menyebabkan lemak tubuh seseorang dapat menurun dengan mengonsumsi air. ${ }^{28}$

Tingkat kecukupan asupan energi dalam penelitian ini tidak mempunyai hubungan yang bermakna dengan persen lemak tubuh. Hasil serupa juga terjadi pada penelitian di Australia yang menunjukkan bahwa tidak terdapat hubungan yang bermakna antara asupan energi dan persen lemak tubuh. ${ }^{29}$ Hal tersebut kemungkinan disebabkan karena pada saat wawancara terjadi the flat slope syndrome dimana terjadi kecenderungan bagi responden yang kurus untuk melaporkan konsumsinya lebih banyak (over-reporting) dan bagi responden yang gemuk cenderung konsumsinya lebih sedikit (under-reporting) sehingga mengakibatkan tidak adanya hubungan antara asupan energi dengan persen lemak tubuh.

Tingkat kecukupan asupan protein juga tidak memiliki hubungan yang berkana dengan persen lemak tubuh. Hal ini dimungkinkan karena umumnya protein tubuh tidak langsung diubah menjadi energi melainkan digunakan untuk membentuk jaringan baru atau mengganti jaringan yang rusak. Beberapa studi menyimpulkan bahwa konsumsi tinggi protein dapat menurunkan persen lemak tubuh. Hormon peptida yang terdapat pada protein berperan sebagai pemberi efek rasa kenyang sehingga diet tinggi protein dapat memerikan rasa kenyang lebih lama dan dapat mengurangi rasa lapar serta menekan terjadinya peningkatan lemak tubuh. ${ }^{10,11,30}$

Tingkat kecukupan asupan karbohidrat dan lemak memiliki hubungan yang signifikan dengan persen lemak tubuh. studi lain di Purworejo menunjukkan hasil bahwa asupan karbohidrat dan lemak berhubungan dengan persen lemak tubuh. ${ }^{9}$ Salah satu jenis karbohidrat adalah serat. Konsumsi serat pada remaja putri berkisar antara 10,1 gram hingga 28,6 gram. Serat makanan pada umumnya memakan waktu yang lebih lama untuk dicerna dan dipecah menjadi glukosa. Hal tersebut dinilai dapat menghindari peningkatan gula darah yang biasanya terjadi setelah mengonsumsi 
karbohidrat sederhana. Lemak merupakan zat gizi penghasil energi terbesar, besarnya lebih dari dua kali energi yang dihasilkan karbohidrat dan protein. Jika asupan berlebih, tubuh lebih cepat menyimpan lemak di jaringan adiposa dibandingkan dengan karbohidrat dan protein sehingga asupan lemak berperan penting dalam peningkatan lemak tubuh seseorang. ${ }^{31}$

Aktivitas fisik dalam penelitian ini tidak mempunyai hubungan yang signifikan dengan persen lemak tubuh. Hasil tersebut berbeda dengan hasil penelitian sebelumnya yang dilakukan di Semarang bahwa aktivitas fisik mempunyai hubungan yang bermakna dengan persen lemak tubuh pada remaja. ${ }^{24}$ Perbedaan hasil ini dapat disebabkan karena aktivitas remaja yang kurang pada remaja yang overfat dan obesitas hampir sebanding dengan remaja yang underfat sehingga aktivitas fisik kurang menggambarkan hubungan yang bermakna dengan persen lemak tubuh.

Hasil uji regresi linier ganda terhadap semua variabel bebas menunjukkan bahwa asupan karbohidrat dan lemak memiliki pengaruh yang bermakna terhadap persen lemak tubuh sedangkan konsumsi air tidak mempunyai pengaruh terhadap persen lemak tubuh pada remaja putri. Variansi persen lemak tubuh digambarkan hanya $26,4 \%$ oleh variansi asupan karbohidrat dan lemak.

Peningkatan metabolisme tubuh setelah konsumsi air lebih rendah dibandingkan dengan setelah konsumsi karbohidrat atau lemak. ${ }^{15,16,32} \mathrm{Hal}$ itulah yang mungkin dapat menyebabkan konsumsi air tidak berpengaruh terhadap persen lemak tubuh. Serat merupakan salah satu jenis karbohidrat kompleks. Serat pada umumnya susah dicerna sehingga membutuhkan waktu yang lebih lama untuk dicerna dan dipecah menjadi glukosa. Hal tersebut menyebabkan tidak terjadi peningkatan gula darah yang diatur oleh hormon insulin. Insulin adalah inhibitor lipolisis dan merangsang terjadinya lipogenesis. Hal itulah dinilai dengan konsumsi karbohidrat jenis serat berkaitan dengan mekanisme penurunan lemak tubuh. ${ }^{33,34}$ Lemak mempunyai efek kenyang yang lebih rendah dibandingkan dengan karbohidrat sehingga dapat meningkatkan asupan energi. Kelebihan energi dari asupan lemak akan lebih mudah disimpan sebagai lemak tubuh sehingga dapat meningkatkan akumulasi lemak tubuh. ${ }^{11,35}$

\section{SIMPULAN}

Terbukti adanya hubungan konsumsi air, asupan karbohidrat, dan lemak dengan persen lemak tubuh pada remaja putri. Tidak terbukti adanya hubungan asupan energi, protein, dan aktivitas fisik dengan persen lemak tubuh pada remaja putri. Asupan karbohidrat dan lemak merupakan prediktor dari persen lemak tubuh pada remaja putri.

\section{SARAN}

Saran bagi subjek yang overfat atau obesitas adalah agar mengontrol dan mengurangi makanan yang mengandung tinggi lemak sehingga dapat meminimalkan terjadinya akumulasi lemak tubuh yang berlebih.

Saran untuk penelitian selanjutnya adalah agar meneliti berbagai macam faktor lain yang mungkin berpengaruh (contoh: total body water) dengan persen lemak tubuh pada remaja putri dan memperhitungkan asupan air dari makanan atau kandungan air pada bahan makanan.

\section{DAFTAR PUSTAKA}

1. Gibney MJ, Barrie MM, John MK, Lenore A. Gizi Kesehatan Masyarakat. Terjemahan Andry Hartono. Jakarta: EGC; 2009.p.102; 206.

2. Thompson JL, Manore MM, Vaughan LA. The Science of Nutrition. 2nd Ed. San Franscisso: Pearson Education, Inc; 2011.p.486-; 272-3.

3. Sjarif DR. Buku Ajar Nutrisi Pediatrik dan Penyakit Metabolik Jilid 1. Jakarta: Penerbit IDAI; 2011.p.230.

4. Ogden CL, Margaret DC, Brian KK, Katherine MF. Prevalence of Obesity in the United States, 2009-2010. NCHS Data Brief. 2012; 82: 1-8.

5. Li Y, et al. Determinants of Childhood Overweight and Obesity in China. British Journal of Nutrition. 2007; 97: 210-5.

6. KEMENKES. RISKESDAS 2013. Departemen Kesehatan: Badan Penelitian dan Pengembangan Kesehatan; 2008.p.218.

7. Astrup A, Tremblay A. Energy Metabolism. In : Gibney MJ, Lanham-New SA, Cassidy A, Voster $\mathrm{HH}$, editors. Introduction to Human Nutrition. 2nd Ed. United Kindom : The Nurtrition Society; 2009.p.31- 48

8. Austin GL, Ogden LG, Hill JO. Trend in Carbohydrate, Fat, and Protein Intakes and Association with Energy Intake Normal-Weight, Overweight, and Obese Indviduals: 1971-2006. Am J Clin Nutr. 2011; 93: 836-43.

9. Adhi DH. Asupan Zat Gizi Makro, Serat, Indeks Glikemik Pangan Hubungannya dengan Persen Lemak Tubuh pada Polisi Laki-Laki Kabupaten Purworejo (skripsi). Program S1 Ilmu Gizi Universitas Indonesia. 2012. Available from: URL:

HYPERLINK http://lontar.ui.ac.id/opac/themes/libri2/detail.jsp?i $\underline{\mathrm{d}=20320225 \& \text { lokasi=lokal }}$

10. Krieger JW, Harry SS, Michael JD, Bobbi LH. Effects of Variation in Protein and Carbohydrate Intake on Body Mass and Composition during 
Energy Restriction: A Meta-regression. Am J Clin Nutr. 2006; 83: 260-74.

11. Papadaki A, et al. The Effect of Protein and Glycemic Index on Children's Body Composition: The DiOGenes Randomized Study. Pediatrics. 2010; 126: e1143-52.

12. Kokkinos P, Myers J. Exercise and Physical Activity. Circulation 2010; 122: 1637-48.

13. Thompson D, Karpe F, Lafontan M, Frayn K. Physical Activity and Exercise in the Regulation of Human Adipose Tissue Physiology. Physiol Rev. 2012; 92: 157-91.

14. Mulyasari I. Pengaruh Asupan Air Terhadap Berat Badan, Indeks Massa Tubuh, dan Persen Lemak. (Tesis). Program Studi Pascasarjana Ilmu Gizi Fakultas Kedokteran Universitas Diponegoro; 2012. Available from: URL: HYPERLINK http://magi.undip.ac.id/index.php?option=com_co ntent\&view=article\&id=363:pengaruh-asupan-airputih-terhadap-berat-badan-indeks-massa-tubuhdan-persen-lemak-tubuh-pada-remaja-putri-yangmengalami-gizi-lebih\&catid=31:versiindonesia\&Itemid $=43$

15. Boschman M, et al. Water-Induced Thermogenesis. J Clin Endocrinol Metab. 2003; 88: 6015-9.

16. Boschmann $\mathrm{M}$, et al. Water Drinking Induces Thermogenesis through Osmosensitive Mechanisms. J Clin Endocrinol Metab. 2007; 92: 3334-7.

17. Dahlan MS. Statistik untuk Kedokteran dan Kesehatan Edisi 5. Jakarta: Salemba Medika. 2011.p.169.

18. WHO. Growth Reference 5-19 Years for Adolescents. 2007. Available from: URL: HYPERLINK http://www.who.int

19. Santoso BI, Hardinsyah, Siregar P, Pardede SO. Air Bagi Kesehatan. Jakarta: Centra Communications; 2011.p.1; 31; 69.

20. Institute of Medicine (IOM). Dietary Reference Intake for Energy, Carbohydrate, Fiber, Fat, Fatty Acids, Cholesterol, Protein, and Amino Acids. Washington DC: National Academies Press. 2005.

21. Gibson RS. Principle of Nutrition Assessment 2nd ed. New York: Oxford; 2005.p.6; 46-7; 214; 3635.

22. IPAQ Research Committee. Guidelines for Data Processing and Analysis of the International Physical Activity Questionnaire (IPAQ) - Short and Long Form. [serial online] 2005. Available from: URL: HYPERLINK http://www.ipaq.ki.se

23. McCarthy HD, TJ Cole, T Fry, SA Jebb, AM Prentice. Body Fat Reference Curves for Children. International Journal of Obesity. 2006; 30: 598 602 .

24. Adityawarman. Hubungan Aktifitas Fisik dengan Komposisi Tubuh pada Remaja (skripsi). Program S1 Kedokteraan Umum Universitas Diponeogro. 2007. Available from URL: HYPERLINK http://eprints.undip.ac.id/22215/
25. Soetjiningsih. Tumbuh Kembang Remaja dan Permasalahannya. Jakarta: Sagung Seto; 2010.p.2; 7-9; 24-7.

26. Prayitno SO, Fillah FD. Perbedaan Konsumsi Cairan dan Status Hidrasi pada Remaja Obesitas dan Non Obesitas. Journal of Nutrition College. 2012; 1(1): 144-52.

27. Putri R. Hubungan antara Derajat Sindrom Pramenstruasi dan Aktivitas Fisik dengan Perilaku Makan pada Remaja Putri (skripsi). Program S1 Ilmu Gizi Universitas Diponeogro. 2013. Available from: URL: HYPERLINK http://eprints.undip.ac.id/41848/

28. Mahmood TA, Sabaratnam A. Obesity: A Ticking Time Bomb for Reproductive Health. Elsevier. 2012.p.29-33.

29. Elliot SA, et al. Associations of Body Mass Index and Waist Circumference with: Energy Intake and Percentage Energy from Macronutrients. Nutr J. 2011; 10: 58.

30. Halton TL, Frank BH. The Effects of High Protein Diets on Thermogenesis, Satiety and Weight Loss: A Critical Review. J Am Coll Nutr. 2004; ;23(5): 373-85.

31. Sarnblad S, Ulf E, Jan A. Dietary Fat Intake Predicts 1-Year Change in Body Fat in Adolescent Girls With Type 1 Diabetes. Diabetes Care. 2006; 29: 1227-30.

32. Tentolouris $\mathrm{N}$, et al. Meal-Induced Thermogenesis and Macronutrient Oxidation in Lean and Obese Women After Consumption of Carbohydrate-Rich And Fat-Rich Meals. Nutrition. 2011; 27: 310-15.

33. Babio N, Balanza R, Basulto J, Bullo M. Dietray Fibre: Influence on Body Weight, Glycemic Control, and Plasma Cholesterol Profile. Nutr Hosp. 2010; 25: 327-40.

34. Babiker, et al. Effects of Gum Arabic Ingestion on Body Mass Index and Body Fat Percentage in Healthy Adult Females: Two-arm Randomized, Placebo Controlled, Double-blind Trial. Nutritional Journal. 2012; 11: 111-8.

35. Coelho DF, et al. Effect of High-Fat Diets on Body Composition, Lipid Metabolism and Insulin Sensitivity, and The Role of Exercise on These Parameters. Braz J Med Biol Res. 2011; 44(10): 966-72. 